Du Preez, Jannie

Universiteit Stellenbosch

\title{
Net maar diere? 'n Tematiese oorsig van die plek van die diereryk in die skepping volgens geselekteerde Skrifgedeeltes
}

\author{
ABSTRACT \\ A thematic survey of the place of the animal kingdom in God's world according to \\ some Scripture passages \\ In a time of growing ecological awareness it may prove valuable to trace the place \\ which the animal kingdom according to the Scriptures takes in God's world. The \\ relevant material unfolds as follows: \\ Every animal unique; \\ The Creator's compassion on animals; \\ Animals as examples to humans; \\ Animal images for God; \\ Animal images for God's people; \\ The messianic kingdom sketched by way of animal images; \\ The significance of animal sacrifices in salvation history; \\ Animal service during Jesus' earthly ministry; \\ The "Prayer relationship" between Creator and animals. \\ As God's image bearers, who have been appointed to rule over the animal world \\ (Gen. 1: 27-28), it is our duty and privilege to behave in such a way towards them \\ that they will thereby be better enabled to fulfil the significance of their existence in \\ God's world.
}

\section{INLEIDING}

In 'n tyd van groeiende ekologiese bewuswording (vgl. Vos \& Müller 1991; Conradie \& Field 2000; Conradie 1996 en 2009) kan dit sinvol wees om na te gaan watter plek die diereryk volgens die Skrif in die skepping inneem. Vanweë die omvangrykheid van die materiaal word van geselekteerde gedeeltes gebruik gemaak om hierdie plek te help bepaal.

Die relevante materiaal word soos volg ingedeel:

1. Elke dier uniek;

2. Die Skepper se deernis teenoor diere;

3. Diere tot voorbeeld vir die mens;

4. Dierebeelde vir God;

5. Dierebeelde vir God se volk;

6. Die Messiaanse vrederyk in terme van dierebeelde geskilder;

7. Die rol van diere-offers in die heilsgeskiedenis;

8. Dierediens tydens Jesus se aardse bediening;

9. Die gebedsverhouding tussen Skepper en dier. 


\section{ELKE DIER UNIEK}

- Genesis 2: 18-20. Die Skeppergod, wat in die eerste skeppingsverhaal (1:1-2:3) met die gewone woord vir God aangedui word ['Êlohim], en in die tweede verhaal (2:3-3:24) met die verbondsnaam HERE God (JAHWE 'Elōhim) skep uit die aarde al die diere en voëls en bring hulle na die mens om uit hulle geledere 'n hulp te soek wat as lewensmaat by hom sou pas. Maar al het Adam uit al hierdie wesens geen geskikte lewensmaat gevind nie, het hy terselfdertyd op bevel van God 'n groot taak verrig deur elke dier en voël 'n naam te gee. Vir die Hebreër was die naam meer as ' $n$ blote etiket, want dit het persoonlikheid en karakter uitgebeeld (Ryle 1914:37; Kroeze 1965:41). Soos wat Adam die diere en voëls genoem het, het God dit aanvaar. Hiermee het Hy self reeds sy unieke verhouding tot die diereryk openbaar.

Uiteraard moet ook die slang getel word onder die geskape wesens. Die "listigheid" (Heb.: ' $\hat{a} r \bar{u} m$ ) waarmee dit in Genesis 3:1 getipeer word, is 'n woord wat op sigself sowel negatief ("listig") as positief ("skrander", "verstandig") verstaan kan word. Maar omdat God self gesien het dat al die diere wat Hy geskape het, goed was (Gen. 1:25), en in Genesis 1:31 alles wat Hy gemaak het selfs as "baie goed" (tô $b m^{e}$ 'od ) getipeer word, moet die woord ook hier in Genesis 3:1 in gunstige sin verstaan word. Volgens die Hebreeuse spraakgebruik word dit in elk geval meesal in gunstige sin gebruik (onder andere agt maal in dié sin in Spreuke, bv. 12:16, 23). Jesus vermaan self sy twaalf apostels om "versigtig" te wees soos die slange, Mat. 10:16 (vgl. Aalders 1933: 127-128). Dit moet dus wees dat die slang hier, in terme van die Genesisverhaal, by implikasie deur ' $n$ bose mag verlei is waarvan die herkoms nêrens in die Skrif deursigtig gemaak word nie (vgl. Durand 1978:73-78; 90-94).

- Job 39-41. 'n Tweede pregnante voorbeeld van diere-identiteit is die lys diere en voëls wat die HERE in sy twisgesprek met Job in hoofstukke 39-41 noem. (Die vertaling ibis en haan in 38:36, soos DGN, vgl. LSB voetnoot, en ander doen, is baie onseker; vgl. Pope 1973:302). Oor elkeen van hierdie wesens word een of meer eienskappe genoem om hulle unieke identiteite aan te dui. Oor sommige, soos die krokodil, word selfs breedvoerig uitgewei (40:20-28; 41:1-25). Die woord wat hier met 'krokodil' vertaal word (liwyātān) lees letterlik 'leviatan'. Maar volgens sy eienskappe word ongetwyfeld die krokodil bedoel. Israel het blykbaar nie 'n spesifieke woord vir die krokodil gehad nie (Kroeze 1964: 450). Om sy unieke identiteit verder te beklemtoon, maak die HERE hier selfs van meer as net 'n tikkie humor gebruik as Hy aan Job in 40:24 vra of Job hierdie gedierte sal probeer mak maak soos ' $n$ voëltjie en aan 'n lyntjie bind as 'n speelding vir sy dogters!

In sy twisgesprek met Job gebruik God al hierdie unieke lewende wesens met hulle besondere unieke eienskappe om in en deur hulle sy onnaspeurlike en onnavolgbare grootheid des te meer vir Job en vir alle mense te laat besef.

- Deur die groot wysheid wat God aan koning Salomo gegee het, het hy insig in die uniekheid van plante en diere gehad en mense daaroor ingelig en daaroor gedig. Na aanleiding van die Oud-Hebreeuse indeling van die diere het hy oor hierdie vier groepe gehandel: eerstens veral oor soogdiere (vee), voorts oor alles wat vlieg, dan alles wat kruip en vierdens alle waterdiere (1 Kon. 4:29-33; vgl Van Gelderen 1937:99). ${ }^{1}$

1 Die unieke identiteit van diere word soms treffend weerspieël in gewone letterkundige werke waarin egte diere die hoofrol speel. Wat die Suid-Afrikaanse letterkunde betref, dink 'n mens onmiddellik aan werke soos sir James Percy Fitzpatrick se Jock of the Bushveld; Eugene Marais se Die siel van die mier; Sangiro (AA Pienaar) se treffende beskrywing van die wel en wee van 'n leeufamilie in Uit oerwoud en vlakte; die 


\section{DIE SKEPPER SE DEERNIS TEENOOR DIERE}

\section{God se omgee vir die dierewêreld straal uit talle plekke in die Bybel.}

- As die skrywer van Genesis 1:19 sê God het al die diere van die veld en die voëls van die hemel na Adam gebring om te sien hoe hy hulle sou noem, roep dit 'n tere omgeebeeld op. Dit is as't ware asof die Skepper met sy eie hand een vir een dier of voël tydsaam na Adam aanbring om hom rustig geleentheid te gee om elke dier of voël se uniekheid te deurgrond en daarvolgens die gepaste naam te gee.

- In 'n artikel oor Genesis 1:1-2:4(a) beklemtoon FE Deist (1987:14) God se besondere sorg vir die lewende skepping deurdat Hy vooraf 'n leefwêreld skep waarin hierdie lewende skepping sou kon oorleef.

- In die sondvloedverhaal in Genesis 6:5-9:17 spreek goddelike genade ook teenoor die dierewêreld. Die Skepper reël vir 'n oorblyfsel van die mensegeslag, maar terselfdertyd ook vir 'n oorblyfsel van diere en voëls, wat soos die mens weer die aarde sal kan bewoon. Treffend staan dit in Genesis 7:24-8:1 dat God ná 150 dae se oorstroming van die aarde aan Noag en aan al die diere in die ark gedink het, en die waters laat begin terugtrek het. Nadat Noag brandoffers geoffer het, het die HERE met hom, sy familie en al die diere en voëls by hom ' $n$ verbond gesluit wat vir alle toekomstige geslagte sou geld: dat mens en dier nie weer op so 'n skaal deur vloedwaters verswelg sou word nie (8:21-9:11). God se reënboog sou hiervan die teken wees.

- Die Wet wat God deur bemiddeling van Moses gegee het, bevat 'n hele aantal maatreëls om die billike behandeling van diere te verseker. So byvoorbeeld beveel die HERE dat sy volk se werksdiere, net soos die Israeliete self en die vreemdelinge by hulle, op die Sabbat moet rus (Eks. 20:10; Deut. 5:14; vgl. Conradie 1996:81). As jy jou vyand se donkie onder sy vrag sien lê, moet jy hom dit help optel, en as jy sy verdwaalde bees of donkie raakloop, moet jy dit beslis na hom terugbring (Eks. 23:4-5). 'n Pasgebore kalf of skaap- of boklam mag eers op die agste dag van sy ma weggeneem word en 'n kalf of lam mag nie op dieselfde dag as sy ma geoffer word nie (Lev. 22:27-28). Wie afkom op 'n voëlnes met 'n ma en haar kleintjies op die grond of in 'n boom, mag die kleintjies neem, maar moet die ma laat wegvlieg (Deut. 22:6-7).

In Deuteronomium 25:4 sê die HERE die Israeliet mag 'n os nie muilband terwyl hy graan dors nie. "Kindness was to be extended to all God's creatures" (Chianeque \& Ngewa 2006: 243). Die Rabbyne het hierdie voorskrif beskou as een van die dinge waarin Israel hom gunstig van al die ander eietydse volke onderskei het (Strack-Billerbeck 1926: 382). As die apostel Paulus in 1 Korinte 9:9 vra of dit miskien oor die os is dat God hom bekommer, is dit binne die verband van hierdie gedeelte duidelik dat Paulus dit nie wil ontken nie (Kirstemaker 1993: 292), maar eenvoudig wil sê: as God billikheid teenoor 'n werkende dier verwag, geld dit des te meer van die menslike arbeider (J Ridderbos 1951: 57; Bouma 1953:98), hier in die Korintebrief in die besonder die apostels as dienaars van God (Groenewald 1980:114; Pop 1965:180; vgl. ook H Ridderbos 1967:140 by 1 Tim. 5:18). Die onderliggende bedoeling ten grondslag van al die wetsbepalinge is die inprent van 'n egte omgeehouding teenoor die dierelewe wat uit God se hand voortgekom het (Ridderbos 1951:40).

- Jona se profesie handel in 'n besondere mate oor die HERE, die God van die genadeverbond, se stryd om sy hartelose profeet aan meer as net die veiligheid en heil van sy eie volksgenote te laat dink; om hom 'n priesterlike hart soos dié van sy Sender te gee, wat hom oor ' $n$ stad met tienduisende kindertjies en baie diere ontferm. Tereg sê J Ridderbos (1949:49) dat die woorde "baie diere" op die oog af 'n vreemde slot vir 'n 
Bybelboek is, maar dat dit in der waarheid 'n kragtige slotakkoord is "voor het loflied op de liefde Gods, dat de kern van deze geschiedenis uitmaakt".

- Psalm 84 is 'n lied van hartstogtelike liefde vir die tempel van die HERE en die digter se smagtende verlange om daarheen op te gaan want hy wil met sy hele wese óór God en vóór God jubel. Hy roep verruk uit dat God se liefde so groot is dat selfs 'n mossie en 'n swaeltjie vir hulle kleintjies daar by sy altare hulle nessies kan maak (v4). Wat ' $n$ tere beeld van goddelike ontferming selfs vir die geringstes van die HERE se lewende skepping! In die uitsending van sy twaalf dissipels in Matteus 10 wys Jesus hulle daarop dat, al is die mense soveel meer werd as die voëls van die hemel, God nogtans ook na die voëls in hulle daaglikse onbesorgde bestaan omsien ( $v v 25-26$ ), sodat selfs nie een mossie, al is hy in terme van geld gereken byna niks werd nie, "hulpeloos op die grond sal val sonder dat julle Vader daarvan weet nie" (v 29, NLV).

- Die gedeelte oor Jahwe se deernis teenoor diere kan afgesluit word met 'n verwysing na Ps. 104:26, waar van 'n gemoedelike verhouding tussen die Skepper en sy skepping gespreek sou kon word. Die Hebreeuse uitdrukking $l^{e}$ śaheq bô word naamlik deur talle nuwere uitleggers en vertalings só verstaan dat Jahwe die Leviatan, 'n gevreesde watermonster (Stradling 1968:729-730), gemaak het om mee te speel (bv. Noordtzij 1973:153; Kraus 1989:303; JB; NLV; DGN; NAB; meer huiwerend Goldingay 2008:192). In ooreenstemming met hierdie speelse vertaling spreek die digter dan ook inderdaad die begeerte uit dat die werk van die HERE hom vreugde mag verskaf (v31). ${ }^{2}$

\section{DIERE TOT VOORBEELD VIR MENS}

In verskillende Skrifgedeeltes word diere se gedrag as voorbeeld vir die mens voorgehou. So kla God by monde van die profeet Jesaja (1:3) dat 'n bees sy eienaar ken en 'n donkie die krip van sy eienaar, maar Israel ken Jahwe nie, hy het geen begrip van wat die HERE doen nie. Daarom sê Snijders tereg (1969:20): “In de Bijbel kan over dieren gesproken word, dat mensen beschaamd worden. Ze weten meer van de echte orde van het leven af, dan de mens, de kroon der schepping." Wanneer Jesus sy dissipels in 'n vyandige, gevaarlike omgewing instuur (Mat. 10:16) soos skape onder wolwe, moet hulle gedrag aan die een kant met versigtigheid soos dié van slange gepaard gaan. Hulle moet hulleself dus nie onnodig in gevaar stel nie. Terselfdertyd moet hulle gedrag egter ook opreg wees soos die duiwe, dit wil sê suiwer van bedoeling en opreg in hulle optrede (vgl. H Ridderbos 1941:202; Van Zyl 2009:1366). In Spreuke 6:6-10 stuur die skrywer die luiaard na die mier, om by dié te leer hoe daar geordend gewerk behoort te word. ${ }^{3}$

\section{DIEREBEELDE VIR GOD}

Treffende dierebeelde dien om God en sy heilshandelinge te identifiseer.

2 Dit moet Bybelgedeeltes soos die voorafgaandes wees wat die kerkhervormer Martin Luther by geleentheid laat sê het: "Wys my hoe jy jou hond behandel, en ek sal jou sê watter soort mens jy is." Van die wêreldbekende Mahatma Ghandi kom die gevleuelde word: "As jy wil weet wat die mentaliteit van 'n nasie is, kyk hoe hulle hul diere behandel (Die Burger, 02-02-2010, briewekolom).

Tydens 'n Christelike Sondagaandprogram oor bekering oor radio RSG gedurende Mei 2010, het 'n teologiese oudstudent vertel dat sy professor in Sendingwetenskap een oggend sy klas geopen het met die gebed: "Here, vergewe my, ek het vanoggend ons kat geskop." Die verteller sê hierdie gebed het tot 'n ingrypende ekologiese bekering in sy eie lewe gelei.

3 In 'n artikel in Leefstylburger van 7 April 2010 word meegedeel dat uit die Amerikaanse hondekosmaker Pup-Peroni se vraelys aan meer as duisend honde-eienaars, meer as twee-derdes sê hulle kan eerder op hulle diere as op hulle beste vriende staatmaak. 
- Toe Israel met sy vertrek uit Egipte regoor die Sinaiberg kamp opslaan, het God vir Moses gesê terwyl hy besig was om teen die berg uit na God te klim (Eks. 19:4): “Julle het gesien wat Ek aan Egipte gedoen het, en hoe Ek julle soos op arendsvlerke veilig gedra en na My toe gebring het." In sy lied aan Israel voor Israel se intog in Kanaän, gebruik Moses die arendsbeeld vir God in uitgebreide vorm om dit vir Israel op die hart te druk dat die HERE alleen vir Israel na veiligheid gelei het (Deut. 32:11-12). Honderde jare later waarsku God egter vir Israel (Hos. 8:1-3) dat sy voortdurende verbondsverbreking sal meebring dat die HERE soos ' $n$ roofvoël op hom sal afpyl deur middel van ' $n$ agtervolgende vyand wat land, volk en tempel sal verower. In Hosea 11:10 is die HERE egter 'n brullende leeu tot redding ten spyte van Israel se aanhoudende ongehoorsaamheid. Op hierdie reddende brul sal die verstrooide volk terugkeer (Hos. 11:10-11): soos 'n swerm voëls na hulle neste (Israel uit Egipte) en soos 'n swerm duiwe na hulle neste (Israel uit Assirië). Maar later in Hosea (13:1-10) hoor 'n mens weer hoe God vir sy volk weens hulle afvalligheid soos 'n verskeurende leeu en luiperd word, soos 'n beerwyfie wie se kleintjies afgeneem is.

- Ook by die profeet Amos word die beeld van God as brullende leeu in verband met God se straffende geregtigheid gebruik. In die eerste geval is dit 'n beeld van straffende geregtigheid teen die volk se afvalligheid (1:2). In die tweede geval word die beeld so aangewend: soos 'n leeu in 'n boom en 'n jong leeu in sy skuilplek brul as hulle buit gevind het, só sal God se ware profeet met siddering spreek as die eintlike leeu, God self, gebrul het $(3: 3-8)$.

- In Joël 3:16 dien die goddelike brul vanuit Sion in Jerusalem in die vorm van 'n sinonieme parallelisme as 'n kragtige onheilsaankondiging aan die nasies rondom Israel (Prinsloo 1990:99 en vgl Jer. 25:30). Maar omdat die tweede deel van Joël 3:16 aan die ander kant eweseer deur middel van 'n kragtige sinonieme parallelisme God se beskerming van Israel aankondiging, sou 'n mens kon sê dat die brul van die leeu in vers 16(a) nie net op die oordeel oor omringende volke dui nie, maar by implikasie ook op die beskerming van God se eie volk Israel.

- In die Nuwe Testament word Jesus Christus sowel lam as leeu genoem. Johannes die Doper roep in verrukking uit: "Kyk! Die Lam (amnos) van God wat die sonde van die wêreld wegneem!" (Joh. 1:29, eie vert.). Dit het Hy gedoen deur homself deur die ewige Gees sonder smet aan God te offer (Heb. 9:14; 1 Pet. 1:19). Op Patmos sien Johannes 'n visioen van die troon van God, met 'n lam (arnion) wat êrens in die middel staan asof hy geslag is, met sewe horings en sewe oë. Hierdie lam is die eintlike leeu uit die stam van Juda (Gen. 49:9). Soos Overduin (1963:90) dit stel: “Onze logica zegt: Een leeuw is een leeuw, en een lam is een lam. Maar God zegt: De leew uit Juda's stam is een lam, en het Lam Gods, dat geslacht wordt, is de leeuw." In Johannes 1:32 sien Johannes die Doper die Heilige Gees op Christus neerdaal in die vorm van 'n duif en op hom bly. Morris (1971:151) vind die simboliek "puzzling and perhaps inexplicable". Die duif was nooit 'n erkende beeld van die Heilige Gees nie. Volgens Geldenhuys (1969:146) simboliseer 'n duif reinheid, onskuld en lieflikheid, en dat dit die simboliek is wat hier volledig en vir goed op Christus oorgedra word.

\section{DIEREBEELDE VIR GOD SE VOLK}

- In sy seënryke afskeidswoord aan sy volk het Moses onder andere die volgende aan sommige van die stamme gesê: "Josef, ja, die tienduisende van Efraim en die duisende van Manasse, is vol majesteit soos 'n eersgebore bul, met horings soos dié van ' $n$ wilde os, om daarmee die volk te deurboor tot by die eindes van die aarde" (Deut. 32:17, eie vertaling). 
Van die stam van Gad sê hy, geseënd is die een wat aan hom grondgebied afstaan; hy lê daar soos ' $n$ verskeurende leeu; sterkes is sy prooi (33:20). Dan is ' $n$ jong leeu wat van Basan af sy prooi bespring (33:22).

- In sowel die Ou as die Nuwe Testament word God se volk as ' $n$ herderskudde getipeer. Wat die Ou Testament betref, dink'n mens feitlik dadelik aan die bekende Psalm 23, waarin die digter homself as een van die HERE se kudde beskou. Die Ou-Testamentiese skrywende profete gaan deurgaans van Israel uit as herderskudde, met die HERE as Opperherder en die konings, profete en priesters almal as herders namens Hom. Enkele voorbeelde: Esegiël 34 is ' $n$ aangrypende hoofstuk oor God se optrede teen vals herders en hoe Hy self sy kudde se herder sal wees. Die profeet Jeremia verlang dat die nasies sal hoor en weet dat die HERE wat Israel verstrooi het, hom sal vergader en bewaak soos 'n herder sy kudde (31:10). Jesaja 40:11 beskryf in tere herderstaal hoe die HERE die lammers van sy kudde in sy arms bymekaar sal maak en aan sy bors dra, terwyl Hy die lammerooie saggies lei (vgl. Miga 2:12).

- In die Nuwe Testament spreek Jesus van sy volgelinge as sy skape vir wie Hy sy lewe aflê (Joh. 10:11). Aan die apostel Petrus dra Hy dit op om hierdie skape op te pas (Joh. 21:15-

17). Miskien word met die lammers in vers 15 (ta arnia) spesifiek die swakkes in die geloof bedoel, soos wat Petrus nog so kort tevore self was (vgl. Groenewald 1980:413). Op sy beurt dra Petrus dit later ook aan die ouderlinge onder sy sorg op om op voorbeeldige wyse die kudde van die Here te versorg (1 Pet. 5:1-4). In 'n aangrypende afskeidswoord dra die apostel Paulus dit aan die ouderlinge van Efese op om as herders hulleself sowel as die hele kudde op te pas wat die Heilige Gees onder hulle sorg gestel het; ja, die gemeente wat God vir homself verkry het "deur die bloed van sy eie Seun", letterlik: deur sy eie bloed. Idios (eie) kom ooreen met die Hebreeuse $y \bar{a} h \bar{\imath} d$ : enigste, geliefde (vgl. De Villiers 1983:118).

- Wat ander beelde vir God se volk betref, sê die HERE by monde van Hosea daar was 'n tyd in Israel (Efraim) se geskiedenis toe hy soos 'n mak koei was wat algaande aan haar eienaar genoegdoening sou kon verskaf het (10:11). Wanneer Israel in ballingskap in Babel moedeloos wonder of die HERE hulle dan vergeet het, word hulle daarvan verseker dat dié wat op die HERE wag, nuwe krag kry om onvermoeid soos met arendsvlerke bo hulle skynbaar uitsiglose omstandighede uit te styg (Jes. 40:27-31). Uit Jesaja 41:14 kom hierdie bemoedigende woord van die God van Israel in terme van 'n tere dierebeeld: Al is Israel klein, Jakob niks meer as ' $n$ wurm nie, die HERE, die heilige van Israel, Hy maak Israel 'n skerp nuwe dorsslee met baie tande. Die profeet Miga verkondig 'n tyd wat sou kom wanneer Israel tussen die nasies sou wees soos 'n leeu tussen wild, of tussen 'n trop skape (5:7).

\section{MESSIAANSE VREDERYK BY WYSE VAN DIEREBEELDE GESKILDER}

Die Messiaanse vrederyk wat deur die profeet Miga voorspel word (4:1-4), word in drie ander Ou-Testamentiese profesieë treffend in terme van dierebeelde geskilder (Jes. 11, veral vv 6-9; 65:17-25, veral v 25; Hos. 2:13-22, veral v 17): vrede tussen diere onderling, vrede tussen mens en dier. Treffend, veral aangesien hierdie profesieë, al het hulle hul voorlopige vervulling êrens in Israel se geskiedenis gevind, hulle volledige vervulling eers in die voleinding plaasvind (vgl. onder andere Nsiku 2006:818; Sundermeier (1966:39-40).

\section{DIE ROL VAN DIERE-OFFERS IN DIE HEILSGESKIEDENIS}


Diere-offers neem so 'n geweldige plek in die gang van die heilsgeskiedenis in, dat dit eintlik op 'n studie in eie reg neerkom. ' $n$ Mens dink byvoorbeeld dadelik aan die boek Levitikus waar, behalwe die spys-, drank- en reukoffer, die volgende diere-offers ook behandel word: die brandoffer, vrede- of dankoffer, sondoffer en skuldoffer (kyk o.a. Van der Waal 1970:78-94, Gorman 2000:147-152). Binne die konteks van die huidige artikel kan slegs daarop gewys word dat al hierdie offers elk op eie wyse deur eeue heen na die finale offer van Christus heengewys het en daarin hulle vervulling en afsluiting gevind het. Kan dit duideliker gestel word as in Hebreërs 9 en 10, veral 10:1-18? Is dit nie asof reeds hier uit die tienduisende voor-Christelike diere-offers iets opstyg van die sugtende skepping waarvan die apostel Paulus so treffend in Romeine spreek nie? lets van die reikhalsende verlange na die komende heerlikheid?

8. DIEREDIENS TYDENS JESUS SE BEDIENING

- Die evangelie van Markus deel mee dat toe Jesus ná sy doop vir veertig dae in die woestyn moes deurbring om deur die duiwel versoek te word, Hy daar saam met die wilde diere was (1:12-13). Uitleggers verskil redelik skerp oor die betekenis hiervan. Terwyl sommige die diere sien as 'n heenwysing na die komende paradystoestand wat deur Christus se gehoorsaamheid geskep sal word (bv. Jeremias 1964:141; Tolmie 2009:1430), sien andere dit as 'n bedreiging vir hom (bv. France 2002:85-87; Cole 2006:1174; Lane 1975:61). Dit is egter moeilik om die Griekse voorsetsel meta ("saam met") wat in verreweg die meeste gevalle so 'n sterk assosiatiewe karakter openbaar (kyk bv. Louw-Nida 1988:794, 803, 806), hier as 'n stryd tussen Christus en die wilde diere te verstaan. Dit suggereer eerder 'n vredige saambly van die diere met Jesus.

- In Kapernaum vang Petrus op bevel van die Here Jesus 'n vis met 'n stater in sy bek, wat as tempelbelasting vir Jesus en Petrus kon dien, al het hulle as Jode nie nodig gehad om dit te betaal nie (Mat. 17:24-27). Al vier evangelies vertel hoedat Jesus by 'n eerste geleentheid deur middel van twee vissies saam met vyf brode duisende mense gevoed het (Mat. 14:17; Mark. 6:38; Luk. 9:13; Joh. 6:9). By 'n tweede geleentheid was daar'n paar visse saam met 7 brode beskikbaar, waarmee Jesus weer eens duisende gevoed het (Matt 15:34; Mark. 8:7). Al drie die Sinoptiese evangelies vertel van Jesus se intog op 'n jong donkie (bv. Mark 11:1-11) - die vervulling van Sagaria se profesie van die regverdige en nederige oorwinnaarkoning wat op die hingsvul van 'n donkie ry (9:9).

9. GEBEDSVERHOUDING “TUSSEN SKEPPER EN DIER”

\subsection{Diere se roep na God}

In drie unieke hoofstukke waarin die HERE in 'n twisgesprek met Job verkeer (39-41), vra God reeds aan die begin vir Job (v 3, NAB; vgl. Ps. 147:9):

Wie gee vir die kraai die kos

wat hy nodig het

wanneer sy kleintjies

om hulp roep na God, rondskarrel vir iets om te eet?

Kroeze (1960:271) sê dit is nie bloot ' $n$ digterlike vertolking van die kraaie se gekrys nie, maar wys ook heen na die voorsienigheid van God oor wilde diere. In sy lofoordenking in Psalm 104 roep die digter uit ( $(\mathrm{2} 2, \mathrm{NAB})$ : 
Die leeus brul op soek na prooi;

hulle vra hulle kos van God.

Vir Weiser (1965:669) is dit die psalmis se teosentriese geloof wat hom in staat stel om selfs die vreeslike gebrul van die leeus as hul gebed tot God te interpreteer. Burden (1991), wat ook die Skepperverheerlikende karakter van die psalm beklemtoon en dit soos andere die "pêrel van die Psalms" noem, sê selfs die jong leeus is van God vir hulle prooi afhanklik, sodat hulle gebrul eintlik dien "as 'n tafelgebed vir kos" (pp. 54-55, 58).

Die boek Joël bevat 'n dringende oproep tot bekering weens 'n naderende dag van oordeel oor die sondes van die volk. Die profeet sê die diere in die veld wag op uitkoms van die HERE af (1:20), want dit is bitter dor en droog. Prinsloo (1990:37) wys daarop dat die Hebreeuse ta'arōg woord wat hier met "wag op uitkoms" vertaal word, nog net in Psalm 42:2 voorkom, waar dit van die wildsbok gebruik word wat na water smag. Die Nederlandse Bybelgenootskap (NBG) vertaal pragtig: "Zelfs de dieren des velds zien smachtend tot u op." 4

\subsection{Ook diere opgeroep tot lof}

Psalm 150 sluit soos 'n magtige slotakkoord Israel se jubelsang af en dra deur sy geweldige fortissimo hierdie loflied deur die eeue totdat die volle openbaring van die HERE se genaderyke verbondsheerlikheid aanskou sal word (Noordtzij 1973:296). Met insluiting van die hallelujaroep aan die begin en aan die einde word die sangers dertien maal opgeroep om die HERE te loof deur die gebruik van die algemeen Semitiese Naam vir God in vers 1 ('Êlōhim) saam met die Verbondsaam Jahwe in vers 6, word sowel Israeliete as nie-Israeliete in die oproep tot lof ingesluit, saam met alles wat asem haal, dus, mens sowel as dier (kyk Burden 1991:195). Met “ alles wat asem haal" sluit die meeste uitleggers net soos Burden ook alle diere in (bv. Noordtzij 1973:296; Okorocha 2006:746). Dieselfde geld vir talle Bybelvertalings (bv. DGN, "alles, was atmet"; LSB, "tout ce qui vit"; REB, "everything that has breath").

In Psalm 145, die laaste in die kort versameling Dawidpsalms (Ps 138-145), sê die digter in vers 21 hy sal die lof van die HERE verkondig, en roep daarmee saam letterlik "alle vlees" op (Heb: qol basar) om die HERE se heilige Naam te loof. Hoewel hierdie uitdrukking nie so uitdruklik alle lewende wesens insluit soos die een in Psalm 150 nie, verstaan talle uitleggers en Bybelvertalers dit nogtans in dié sin; dus, met insluiting van alle diere (Burden 1991:169; Weiser 1965:828; DGN, "alles, was lebt"; LSB, "toute creature"; DBX, "zonke izidalwa"; NIV, "everything that has breath"). Alles en almal wat in die skepping bestaan en leef, bestaan en leef sinvol deur onafgebroke lof aan die Skepper, sy dit onbewustelik of bewustelik.

\subsection{Spontane lof aan God deur al wat leef}

Waar die twee psalms in die vorige afdeling 'n oproep laat hoor tot al wat leef om God te loof, laat die troonvisioen in Openbaring 4 en 5 'n spontane uitroep hoor van lof aan God deur al wat leef.

Daar is eerstens die visioen van die vier lewende wesens rondom die troon in 4:6. Hulle lyk agtereenvolgens soos 'n leeu, 'n kalf, 'n mens, en 'n vliegende arend. Alford (1861:598-599) noem dertien van die menigte verklarings vir hierdie gesig sedert die dae van Victorinus. Daar

4 In 'n digbundel getitel Le mieux aimé : "Die mees geliefde”, 1947, stel Carmen Bernos de Gasztold allerlei diere en voëls in gebede tot God aan die Woord. Die afgeleefde perd sê hy het as nuttelose dienaar nog net een versoek: "Mag deur u goedheid 'n sagte einde op my wag." Die muisie sê hy is so klein en grys. Hoe kan die Here hom onthou? Hy vra van die Here net so 'n ietsie om aan te knibbel ... vér van die kloue van daardie groenoogduiwel. Die donkie vra dat hy eendag sy broertjie van die kersfeeskrip mag ontmoet. Die skilpad se gebed begin met die versugting: "Net so 'n klein bietjie geduld o Heer, ek kom ..." 
is verskillende ooreenkomste met die vier wesens in die roepingsvisioene van Jesaja (hfst. 6) en Esegiël (hfst. 1), soos byvoorbeeld die vlerke. Maar Johannes maak op eie wyse van die beelde in die Ou Testament gebruik. Kenmerke soos die getal vier, en die mens- en drie diergesigte, maak dit nog die natuurlikste om saam met die meeste uitleggers die vier wesens as verteenwoordigers van die hele lewende skepping te sien. Dus met insluiting van alle diere (bv. kommentare van Greijdanus, Lenski, Groenewald, König, Osborne, Du Rand). Johannes hoor hulle dag en nag in spontane aanbidding die Here God, die Almagtige, prys as die Driemaalheilige wat was, en wat is en wat kom (4:8).

In die tweede deel van die troonvisioen, naamlik hoofstuk 5, hoor Johannes teen die einde daarvan (v13) 'n geweldige loflied spontaan uit die skepping opstyg tot God en die Lam op die troon. Johannes sê dis letterlik die hele skepping (Grieks: pan ktisma) en spesifiseer dit dan nog deur te sê alles in die hemel en op aarde en onder die aarde en op die see, alles daarin, sodat Du Rand (2007:260) tereg daarvan sê dat dit nie net van mense geld nie, maar op alles en almal wat geskep is. Keulers (1956:287) stel dit nog meer eksplisiet deur te sê ja, "ook de redeloze en levenloze" van die skepping. Hiervolgens kan 'n mens dus sê dat selfs die mikroskopies klein en sterrenagtelik groot dele van die skepping op hulle eie wyse, hoe onhoorbaar miskien vir ons, saam met die res van die skepping hulle loflied sing. Maar dan kan 'n mens seker met des te meer sekerheid sê dat die ganse diereryk, met sy ontsaglike verskeidenheid van stemme, deel vorm van die heelal se spontane loflied tot God. ${ }^{5}$ Die derde strofe van lied 509 in Liedboek van die Kerk (2001) verwoord in alle eenvoud pragtig iets van hierdie dierelof aan God:

Die diere op die aarde,

die visse in die see,

die mossie en die arend, die blomme, veld en vee, met al sy ander werke, verkondig dag en nag sy goedheid sonder perke; die grootheid van sy mag

As die hele skepping dan die diepste sin van sy bestaan vind in die spontane lof aan sy Skepper, soos wat so duidelik uit die bewoording van die loflied in Openbaring afgelei kan word, sou 'n mens moet vra: Is dit nie die heerlike ekologiese plig en voorreg van die mens wat as beeld en verteenwoordiger van God op aarde oor die diereryk aangestel is (Gen. 1:26), om teenoor diere, sowel individueel as kollektief, só op te tree dat hulle die sin ook van húlle bestaan hierdeur steeds beter sal kan verwerklik nie?

\section{BRONNELYS}

Aalders, G Ch 1933. Genesis (KV). Kampen: JH Kok.

Alford, H 1861. Apokalupsis loannou. The Greek Testament IV/2. London: Rivingtons.

Bouma, C 1953. I, II Timotheus en Titus, Filémon (KV). Kampen: JH Kok.

Burden, JJ 1991. Psalms 101-119, en 120-150. Kaapstad: NG Kerk-Uitgewers.

5 Vergelyk hier ook "Het schrijverke" van die diep-gelowige Vlaamse priesterdigter Guido Gezelle (18301899) in sy bundel Als de ziele luistert (1949). As mense van die woelige waterkewertjie bekend as skrywertjie wil weet wat hy as "krinklende winklende waterding" daar so lustig in kringe op die staande water skryf, antwoord hy die vraer ietwat geïrriteerd of dié dan nie self kan lees wat God vir hulle as skrywertjies geleer het nie:

"Wij schrijven, herschrijven en schrijven nóg,

Den heiligen Name van God." 
Chiqaneque, LC \& Ngewa, S 2006. Deuteronomy, in Africa Bible Commentary. (Gen Ed T. Adeyemo), 209254. Zondervan: Word Alive Publishers.

Cole, VB 2006. Mark, in Africa Bible Commentary. (Gen. Ed. T Adeyemo). Zondervan: Word Alive Publishers, 1171-1202.

Conradie, E \& Field, D 2000. A rainbow over the land (A South African guide on the church and environmental justice. Sybrand park: Western Cape Provincial Council of Churches.

Conradie, Ernst 1996. Rus vir die aarde. Kaapstad: Lux Verbi.

Conradie, Ernst 2009. Uitverkoop? (In gesprek oor die verbruikerskultuur). Wellington, Lux Verbi BM.

Deist, FE 1987. Genesis 1:1-2:4(a): World picture and world view. Scriptura 22:1-17.

De Villiers, JL 1983. Die Handelinge van die Apostels II. Kaapstad: NG Kerk-Uitgewers.

Du Rand, J 2007. Die A-Z van Openbaring. Vereeniging: CUM.

Durand, JJF 1978. Die sonde. Pretoria: NG Kerk-Boekhandel.

France, RT 2002. The Gospel of Mark (NIGTC). Carlisle: The Paternoster Press.

Geldenhuys, N 1969. The Gospel of Luke (NLCNT) London: Marshall, Morgan \& Scott.

Goldingay, J 2008. Psalms. Grand Rapids, Michigan.

Gorman, FH 2000. Leviticus. The Harper Collins Bible Commentary. (Gen Ed. James L

Mays). Harper San Francisco: 145-166).

Greijdanus, S 1952. De Openbaring des Heeren aan Johannes. KNT. Amsterdam: AH van Bottenburg.

Groenewald, EP 1986. Die Openbaring van Johannes. Kaapstad: NG Kerk-Uitgewers.

Groenewald, EP 1980. Die Eerste Brief aan die Korinthiërs. Kaapstad: NGK-Uitgewers.

Keulers, Jos 1956. De Katholieke Brieven en het Boek der Openbaring. Roermond en

Maaseik: JJ

Romen \& Zonen.

Kirstemaker, SJ 1993. I Corinthians (NTC). Grand Rapids: Baker Books.

Kraus, H-J 1989. Psalms 60-150. Minneapolis: Augsburg.

Kroeze, JH 1960. Het Boek Job (KV). Kampen: Kok.

Kroeze, JH 1964 Het Boek Job (COT). Kampen: JH Kok.

Kroeze, JH 1965. Handboek Bybelse Geskiedenis (die Ou Testament). Pretoria-Potchefstroom-Kaapstad: Interkerklike Uitgewerstrust.

Lane, W 1975. Commentary on the Gospel of Mark (NICONT). Grand Rapids, Michigan: Eerdmans.

Lenski, RCH 1957. The Interpretation of John's Revelation. Columbus: Wartburg Press.

Liedboek van die kerk. Kaapstad: NG Kerk-Uitgwers, 2001.

Louw, JP \& Nida, EA 1988. Greek-English Lexicon I-II. New York: United Bible Societies.

Morris, L 1971. The Gospel according to John (NLCNT). London: Marshall, Morgan \& Scott.

Noordtzij, A 1973. De Psalmen III (KV) Kampen: JH Kok.

Nsiku, EK 2006, in Africa Bible Commentary. (Gen Ed T Adeyemo.) Zondervan: Word

Alive Publishers, 808-852.

Okorocha, C 2006. Psalms, in Africa Bible Commentary(Gen. Ed T Adeyemo). Zondervan: Word Alive Publishers, 605-746.

Osborne, GR 2002. Revelation. Grand Rapids, Michigan: Baker Academic.

Overduin, J 1963. Prophetische vergezichten. Kampen: JH Kok.

Pop, FJ 1965. De Eerste Brief van Paulus aan de Corinthiërs. Nijkerk: Callenbach.

Pope, MH 1973. Job (The Anchor bible). New York: Doubleday.

Prinsloo, WS 1990. Die boek Joël. Kaapstad: NG Kerk-Uitgewers.

Ryle, HE 1914. The Book of Genesis. Cambridge University Press.

Ridderbos, H 1967. De Pastorale Brieven (CNT). Kampen: JH Kok.

Ridderbos, J 1951. Deuteronomium II. (KV). Kampen: JH Kok.

Ridderbos, H 1941. Mattheüs (KV). Kampen: JH Kok.

Ridderbos, J 1949. De Kleine Propheten II (KV). Kampen: JH Kok.

Snijders, LA 1969. Jesaja I (POT). Nijkerk: Callenbach.

Strack, HL \& Billerbeck, P 1926. Kommentar zum neuen Testament III. München.

Stradling, DG 1968. Leviathan, in The New Bible Dictionary. London: Inter-Varsity Press.

Sundermeier, Theo 1966. Die profeet Hoséa (Teologiese Boekreeks 4). Genadendalse

Drukkery

Terrien, S 2003. The Psalms. Grand Rapids: Eerdmans. 
Tolmie, F 2009. Markus, in Die Bybellennium (red. FJ van Rensburg \& M Nel)

Vereeniging: CUM, 1425-1485.

Van Gelderen, C 1937. Koningen (deel 1). Kampen: JH Kok.

Van Selms, A 1967. Genesis I (POT). Callenbach: Nijkerk.

Van Zyl, HC 2009. Matteus, in Die Bybellennium (red. FJ van Rensburg \& M Nel). Vereeniging: CUM, 13371424.

Van der Waal, C 1970. Sola Scriptura I. Goes: Oosterbaan \& Le Cointre NV, 78-94.

Vos, C \& Müller, J (red.) 1991. Mens en omgewing. Halfway House 1685, ORION.

Weiser, A 1965. The Psalms (OTL). London: SCM Press.

Bybelvertalings

DBA. Die Bybel in Afrikaans. Britse en Buitelandse Bybelgenootskap, 1962.

DBX. Ibhayibhile (The Bible in Xhosa). The Bible Society of South Africa, 1997.

DGN. Die Bibel. Die Gute Nachricht in heutigem Deutsch. Stuttgard: Deutsche Bibelgesellschaft, 1982.

JB. The Jerusalem Bible. London: Darton, Longman \& Todd, 1966.

LSB. La Sainte Bible (version Semeur), 2000.

NAB. Nuwe Afrikaanse Bybel. SA Bybelgenootskap (1983-vertaling).

NBG. Bijbel in de Nieuwe Vertaling. Amsterdam: Het Nederlandsch Bijbelgenootschap, 1961.

Moffat. The Moffat Translation of the Bible. London: Hodder \& Stoughton, 1953.

NIV. Holy Bible (New International Version). International Bible Society; Bible Society of South Africa, 2006.

NLV Die Bybel. Nuwe Lewende Vertaling. Vereeniging: CUM, 2007.

REB. The Revised English Bible. Oxford University Press; Cambridge university Press, 1989.

TEV. Good News Bible. Collins: Fontana, 1976.

\section{TREFWOORDE}

ekologie

heilsgeskiedenis

diereryk

diere-identiteit

dierebeelde

dieregebede

aanbidding

\section{KEY WORDS}

ecology

salvation history

animal kingdom

animal identity

animal images

animal prayers

worship

Kontakbesonderhede:

Dr J du Preez

Schonenberg 31

Privaatsak X3

Somerset-Wes 7129

Tel: (021) 8500240 